\title{
Profile of the Interpreting Ability of Students on Static Fluid
}

\author{
Nurmisanti $^{1, *)}$, Yudi Kurniawan ${ }^{2}$, Riski Muliyani ${ }^{3}$ \\ STKIP Singkawang, Singkawang, Indonesia \\ nurmisanti92@gmail.com ${ }^{1}$, yudikurniawan1012@gmail.com ${ }^{2}$, kikiriski1012@gmail.com ${ }^{3}$ \\ ${ }^{*}$ Corresponding author
}

Keywords:

Interpreting, Ability, Static

Fluid

\begin{abstract}
The purpose of this study was to get a description of the students' ability to interpret the static fluid material. This research was a quantitative descriptive study and the sample was taken by purposive sampling technique with a total sample of 26 students at one of the Madrasah Aliyah in the city of Singkawang. To achieve this goal, students had filled in questions about static fluids in a multiple-choice test. The results of this study were a quantitative description of the student's ability to interpret the static fluid material. The interpretive ability category was adapted from the n-gain category. The results showed that the category of students' ability to interpret the concept of hydrostatic pressure and Archimedes principle was in the high category with a percentage of $88 \%$ and on the Pascal principle it was categorized as low with a percentage of $19 \%$. The results of this study can be a reference for future researchers to improve aspects of understanding interpreting categories in students.
\end{abstract}

\section{INTRODUCTION}

Physics is one of the natural sciences that has contributed to the development of technology (Amir, Muris, \& Arsyad, 2015: 202). Physics is a collection of systematic discoveries in the form of facts, principles, laws, formulas, theories, models, and concepts (Sutrisno, 2006: 3). Static fluids are one of the concepts studied in physics. Static fluids consist of several laws and principles, three of which are the law of hydrostatic pressure, the Pascal principle, and the Archimedes principle.

The understanding aspect consists of several categories namely interpret, exemplify, classify, summarize, reference, compare and explain (Rosdianto, Murdani, \& Hendra, 2017). Interpretation skills occur when students can change information from one form to another, such as pictures from words, words into pictures, numbers into words, words into numbers, musical notes into musical sounds, and the like (Anderson and Krathwohl, 2010: 106). The purpose of this study was to describe the students' ability to interpret the static fluid material. Researchers have the hope that these results can be useful for future researchers and become basic data for future research. 


\section{METHOD}

This research is a quantitative descriptive study to describe the ability to interpret students on static fluid material. The population in this study were all students of class XI IPA at one of the Madrasah Aliyah in the city of Singkawang. The sampling technique used purposive sampling, amounting to 26 students. The data collection technique used in this study was a multiple-choice test. The test consists of three static fluid concepts that describe the student's ability to interpret. The distribution of static fluid concepts and the ability to interpret students can be seen in Table 1 .

Table 1

Distribution of Concept and Interpreting Aspects of Students

\begin{tabular}{lll}
\hline No. & \multicolumn{1}{c}{ Concept } & \multicolumn{1}{c}{ Interpreting Aspects } \\
\hline 1 & Hydrostatic Pressure & Converts graphics into words \\
2 & Pascal Principle & Converts formulas into words \\
3 & Archimedes Principle & Converts formulas into words \\
\hline
\end{tabular}

\section{RESULTS AND DISCUSSION}

To describe the students' ability to interpret the static fluid material, the interpretive ability category was adapted from the n-gain criteria as shown in Table 2.

Table 2

Category of Interpreting Aspect

\begin{tabular}{cc}
\hline Percentage of Interpreting Aspects & Category \\
\hline $0,0 \% \leq$ Interpret $\leq 29 \%$ & Low \\
$30 \% \leq$ Interpret $\leq 69 \%$ & Moderate \\
$70 \leq$ Interpret $\leq 100 \%$ & High \\
\hline
\end{tabular}

Table 2 states the criteria for the ability to interpret students. Fig. 1 is the data on the results of students' ability to interpret the static fluid material.

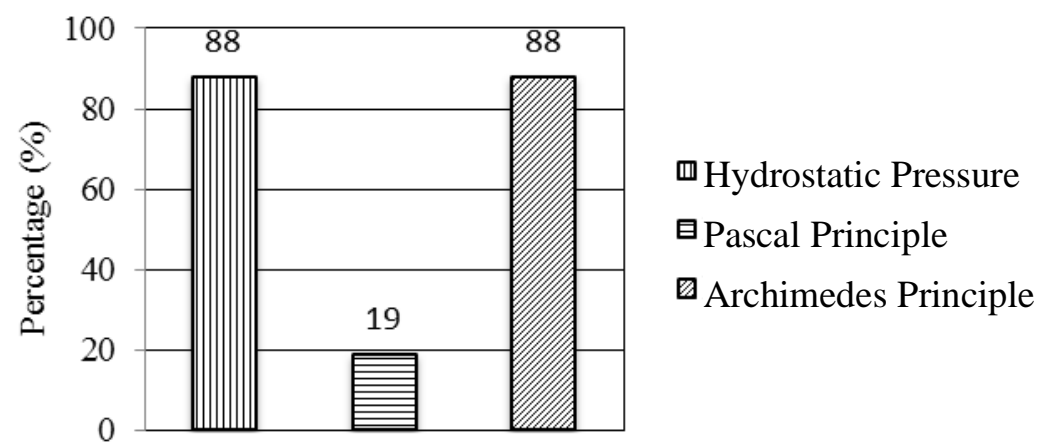

Fig. 1 Data of the Interpreting Ability of Students on Static Fluid

Based on Fig. 1, it appears that the students' ability to interpret the concept of hydrostatic pressure and the Archimedes principle is in the high category and the concept on the Pascal principle is in a low category. In the concept of hydrostatic pressure, the measured interpretive ability is to change the graph into words with a percentage of $88 \%$ in the high category, and in Pascal principle, the measured interpretive ability is to change the formula into words with a percentage of $19 \%$ in the low category. The low ability to interpret students on Pascal principle is because students change the formula incorrectly. This is following the statement of Ichtyaranisa et al. (2013: 9), namely the error of 


\section{IJ-MDS International Journal of Multi Discipline Science (IJ-MDS)}

Vol. 3 No. 1 (2020)

e-ISSN: 2615-1707. Page: 30-32

changing the form of the formula is $4.95 \%$, this error is due to students not understanding the concept of the item. Therefore, a learning model or method is needed that can give students the freedom to learn according to their learning styles so that the learning that occurs helps students understand concepts, especially in the aspect of interpreting (Sari \& Sumarli, 2019).

\section{CONCLUSION AND SUGGESTION}

Based on the results and discussion, it can be concluded that the category of students' ability to interpret the concept of hydrostatic pressure and Archimedes principle was in the high category with a percentage of $88 \%$ and Pascal principle in the low category with a percentage of $19 \%$. It is hoped that the results of this study can be used as a reference for further research and can improve students' interpretive skills.

\section{REFERENCES}

Amir, Musdalifa., Muris., \& Arsyad, Muhammad. (2015). Pengembangan Perangkat Pembelajaran Berbasis Pengalaman Pada Peserta Didik Kelas XI IPA SMA Negeri 9 Pinrang. Jurnal Sains dan Pendidikan Fisika (JSPF), 11(3).

Anderson, Lorin W., \& Krathwohl, David R. (2010). Kerangka Landasan untuk Pembelajaran, Pengajaran, dan Asesmen. Translated by Agung Prihantoro. Yogyakarta: Pustaka Pelajar.

Ichtyaranisa et al. (2013). Remediasi Kesalahan Siswa Menyelesaikan Soal Fluida Statis Menggunakan Model Make A Match di SMA.

Rosdianto, H., Murdani, E., \& Hendra. (2017). The Implementation of POE (Predict Observe Explain) Model to Improve Student's Concept Understanding on Newton's Law. Jurnal Pendidikan Fisika, 6(1), 55-57.

Sari, P. M., \& Sumarli, S. (2019). Optimalisasi Pemahaman Konsep Belajar IPA Siswa Sekolah Dasar melalui Model Pembelajaran Inkuiri dengan Metode Gallery Walk (Sebuah Studi Literatur). Journal of Educational Review and Research, 2(1), 69-76.

Sutrisno. (2006). Fisika dan Pembelajarannya. http://File.Upi.Edu/Direktori/Fpmipa/Jur._Pend._Fisika/195801071986031-

Sutrisno/Pelatihan/Ls/Fisika_Dan_Pembelajarannya.Pdf (Accessed on March 31, 2016). 